\title{
An Analysis on the Perception of Small Ruminant Breeders to Climate Change and The Factors Affecting Adaptation: A Case Study of Karaman Province
}

\section{Murat DEMIRBÜK ${ }^{1 *}$}

ABSTRACT: Agricultural production relies heavily on the climate, which has been changing constantly in recent years. This study conducted in order to determine small ruminant breeders' perception of climate change, their adaptation strategies and barriers to adaptation. The meteorological data obtained from Karaman Provincial Directorate of Meteorology between 1970-2019 were used to notice the changes in climate. Primary data was obtained through a survey with the members of Sheep and Goat Breeders Union. The sample size, according to the random sampling method, composed 118 breeders the data was analyzed by binary logistic regression method. The dependent variable in the model is adaptation status and 12 independent variables were determined. According to the results of logistic regression analysis, age, experience, attitude towards innovations, believing or not believing in climate change and witnessing extreme weather events in the region were found statistically significant. While the others, gender, educational background, number of animals, farm size, other income, agricultural income and total income, were found statistically insignificant $(\mathrm{P}<0.05)$. The usage of concentrate feed, forage crop production, diversity in agricultural production and breeding more resistant species against diseases and droughts were identified as major adaptation practices. Lack of information was found the most important barrier to adapt to climate change. The training activities should be organized for regular notifications concerning the impacts of climate change on agricultural production and future projection. Restructuring government aids in consideration of regional climate conditions shall facilitate the adaptation of breeders. The detailed studies are needed in Turkey. All sub-components of agricultural production should be discussed separately.

Keywords: climate change, extreme weather events, food security, small ruminant

\section{Küçükbaş Hayvan Yetiştiricilerinin İklim Değişikliği Algısı ve Adaptasyonu Etkileyen Faktörler Üzerine Bir Analiz: Karaman İli Örneği}

ÖZET: Tarımsal üretim büyük oranda iklime dayanmaktadır ve iklim son zamanlarda sürekli değişmektedir. Bu çalışma, küçükbaş hayvan yetiştiricilerinin iklim değişikliği algılarını, adaptasyon stratejilerini ve adaptasyonun önündeki engelleri belirlemek için yapılmıştır. İklim değişikliğini görebilmek için Karaman Meteoroloji Müdürlüğünden alınan 1970'den 2020 yılına kadar olan meteorolojik veriler kullanılmıştır. Birincil veriler Damızlık Koyun ve Keçi Yetiştiricileri birliği üyelerinden anket yoluyla elde edilmiştir. Örneklem büyüklüğü 118 'dir. Verilerin analizinde ikili lojistik regresyon methodu kullanılmıştır. Modelde bağımlı değişken adaptasyon durumu olup, 12 bağımsız değişken belirlenmiştir. Regresyon analizi sonuçlarına göre, yaş, deneyim, yeniliklere karşı tutum, iklim değişikliğine inanıp inanmama durumu ve ekstrem hava olaylarına tanık olma istatistiksel olarak anlamlı bulunmuştur $(P<0.05)$. Cinsiyet, eğitim durumu, hayvan sayısı, çiftlik büyüklüğü, diğer gelir, tarımsal gelir ve toplam gelir ise istatistiksel olarak anlamsız bulunmuştur. Kesif yem kullanımı, yem bitkileri üretimi, tarımsal üretimde çeşitlilik ile hastalık ve kuraklığa dayanıklı ırkların tercih edilmesi başlıca adaptasyon seçenekleri olarak tespit edilmiştir. Bilgi yetersizliği, iklim değişikliğine adaptasyonun önündeki en önemli bariyer olarak görülmüştür. İklim değişikliğinin etkilerini anlatacak ve gelecek projeksiyonları içeren eğitim programları organize edilmelidir. Devlet desteklerinin bölgesel iklim koşullarına göre yeniden organizasyonu adaptasyonu kolaylaştıracaktır. Türkiye'de konu ile ilgili detaylı araştırmalara gereksinim vardır. Tarımsal üretimin tüm alt kategorileri ayrı ayrı ele alınmalıdır.

Anahtar Kelimeler: Aşırı hava olayları, gıda güvenliği, iklim değişikliği, küçükbaş hayvan, uyum

${ }^{1}$ Murat DEMIRBÜK (Orcid ID: 0000-0001-5535-1949), İl Tarım ve Orman Müdürlüğü, Kırsal Kalkınma ve Örgütlenme Şubesi, Sivas, Türkiye

*Sorumlu Yazar/Corresponding Author: Murat DEMIRBÜK, e-mail: mdemirbuk@ hotmail.com 


\section{INTRODUCTION}

Agricultural production relies heavily on the climate, which has been changing constantly in recent years. The information about the impacts of climate change on agricultural production have been developed considerably in last 20 years (FAO, 2015).

The severe rainfalls and floods, forest fires, climate events, new pandemics, new strains in different pathogens and viruses, irregular bacterial growth, high incidence rate of pests in recent years refer to the global indicators of direct and severe environmental changes (Yadav et. al., 2019). When only climaterelated disasters (floods, drought, tropical storms) are considered, the share of damage and loss absorbed by agriculture increases to 26 percent (FAO, 2018).

Such changes threaten the sources of income for the millions of people residing especially in rural areas. The underdeveloped and vulnerable local communities, farmers and women are under the mostly affected groups (MEU, 2012). Rural migration, as a result of climate change, also must be considered seriously. Not only its economic effect but also its social effect in urban area. Of all natural hazards, floods and storms have contributed the most to displacement recorded in 2019, followed by droughts (WMO, 2020).

In order to produce sustainable foods and to support the increasing world population, it is highly important to reduce the impacts of climate change and to ensure farmers to adopt the changing environment.

In this day, the agriculture industry is considered as the victim of climate change, but also as one of the reasons for this phenomenon. The destructive impacts of climate change on agriculture should be addressed with the development of ecosystem services, food security, biological diversity and sustainability (MEU, 2012). Increasing the resource productivity in agriculture and the resistance to climate risks are key actions to overcome such challenges (FAO, 2019).

Researchers have been conducting several studies to determine farmers' perception to climate change and to analyze how they adapt the global climate change. Such studies have been conducted for Africa (Derassa et. al., 2011, Mbakwe et. al., 2016, Zizinga et. al., 2017, Fadina and Barjolle, 2018, Atsiaya et. al., 2019, Kinuthia et. al., 2018), Asia (Kim et. Al.,2012), Europe (Woods et. al., 2017; Mitter et. al., 2019) and USA (Mase et. al., 2016).

The studies concerning climate change and agriculture in Turkey were given in chronological order. A research project was conducted in Karapinar District of Konya Province in order to give certain recommendations for the farmers about the adaptation to climate change. Karapinar District shares the border with Merkez District of Karaman Province subjected to this study (Soylu and Sade, 2012). Akalın (2014) analyzed the general situation of climate change together with its impacts on agriculture. Further studies concerning the perception of farmers to climate change were conducted by Polat and Dellal (2016), and Çaltı and Somuncu (2018).

Historically, the studies analyzing the impacts of climate change on livestock production are fewer than crop production (FAO, 2015). One of these studies were performed in Nigeria (Esiobu and Onubuogu, 2014) in order to determine tendency, perception and adaptation options of livestock producers towards climate change.

According to FAO (2017), small ruminants have further advantage in terms of fertility. Therefore, it is possible for the small ruminants to breed more comparing to cattle following a drought season. Livestock makes major contributions to certain micro-nutrients such as calorie, protein, B12, iron and calcium. Livestock generates $17 \%$ of calories and $33 \%$ of proteins consumed globally (FAO, 2017). 
The breeders of small ruminants were preferred for this study due to less researches about these professionals. The relevant responses were searched for the following questions: What is the perception of breeders to climate change? Which adaptation strategies have been preferred by the breeders? What are the obstacles encountered by the breeders during the adaptation phase to climate change? A similar study fails to be found in Turkey.

The climate data for last 50 years were analyzed in the research area. The data concerning the perception of breeders to climate change and the adaptation strategies were collected by surveys. The stated data was then analyzed by the logistic regression method.

The responses to the research questions (socio-economic characteristics of the breeders, the level of perception to climate change, relevant needs and adaptation strategies) shall assist in improving or changing the current approach to a sustainable livestock production.

\section{MATERIALS AND METHODS}

The research area was preferred consciously since a local sheep species exists in this region and small ruminant breeding is the key source of income. White Karaman is an indigenous breed of this region. The study was performed in Central District of Karaman Province. The district is located in the southern part of Central Anatolia Region between the northern latitude of 37.11 and the southern latitude of 33.15. The altitude is 1033 meters.

The primary data used in this study were obtained by the one-to-one surveys conducted with the members of Sheep and Goat Breeders Union in Central District of Karaman Province. The Union has 1356 members and the members have 161.000 small ruminants in total. Since the population variance was known, the following formula was used to determine the sample size (Yamane, 2006):

$$
n=\frac{N *(Z \alpha / 2)^{2} * \sigma^{2}}{(N-1) d^{2}+\left(\frac{Z \alpha}{2}\right)^{2} * \sigma^{2}}
$$

The sample size was calculated as 118. In this equation, " $\mathrm{n}$ " refers to the sample size (118), "N" refers to population (1356), " $\mathrm{Z} \alpha / 2$ " refers to standard normal distribution value (1.96), " $\sigma^{2}$ " refers to variance (9688.67) and " $\mathrm{d}$ " refers to the difference between sample average and population (17).

The incidence of adaptation to climate change was analyzed for the breeders by the binary logistic regression method. The reduced binary logit model is described as $\mathrm{Y}=\mathrm{f}(\mathrm{X} 1, \mathrm{X} 2, \ldots, \mathrm{X} 12)$.

The incidence of adaptation strategies between the breeders were considered as dependent variables. In this respect, "Y" refers to dependent variable whereas adaptation status is indicated with "0-yes" and "1-no". Independent variables are described as follows: X1 = Age, X2 = Gender (1 Men, 2 Women), X3 = Education (1 Literate, 2 Primary education, 3 Secondary, 4 High school, 5 University), $\mathrm{X} 4=$ Experience, $\mathrm{X} 5=$ Number of animals, $\mathrm{X} 6=$ Farm size, $\mathrm{X} 7=$ Believing or not believing in climate change (1 Yes, 2 No), X8 = Attitude towards innovations (1 Accept immediatly, 2 After others, 3 No), X9 = Occurrence of extreme climate events ( 1 Yes, 2 No), X10 = Other income (1 Yes, 2 No), X11 = Agricultural income and X12 = Total income.

During the analysis phase, gender, other income, attitudes towards innovations, occurrence of extreme climate events and believing or not believing in climate change were specified as categorical variables and first group was taken as the reference group for all categorical variables. 
The meteorological data used in this study (1970-2020) were obtained from Provincial Meteorological Directorate of Karaman Province. The climate data was then summarized through the graphics developed with Excel software and correlation analysis was duly performed.

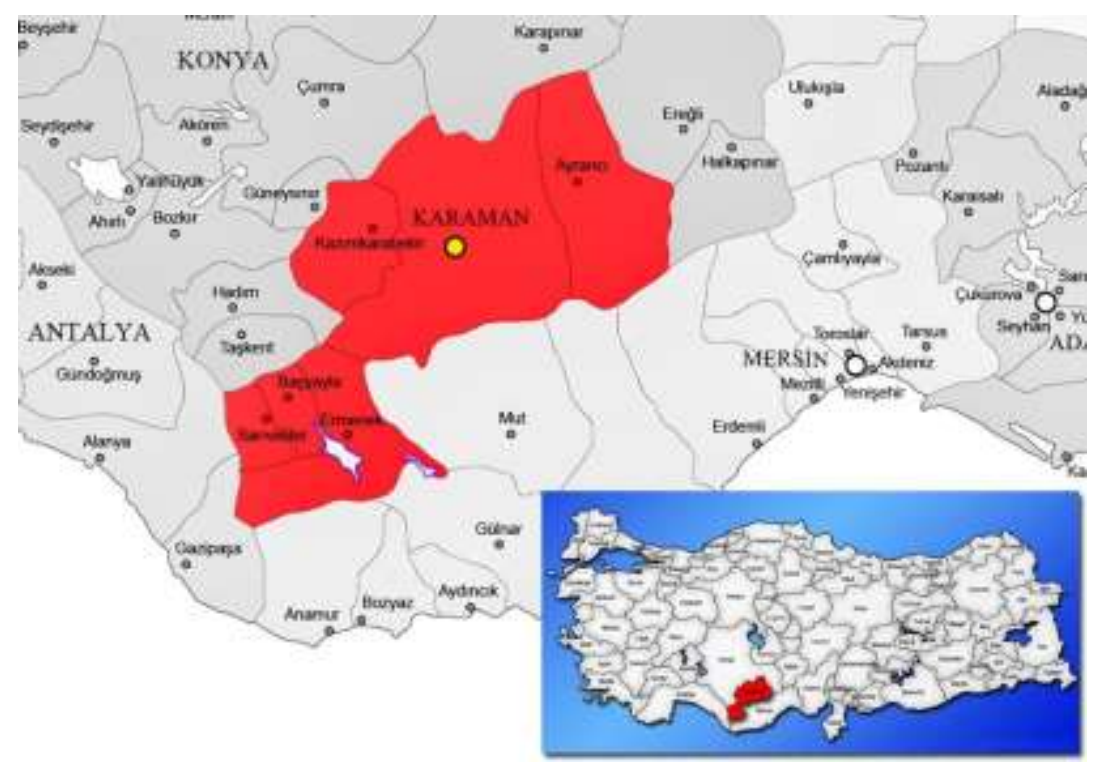

Figure 1. Karaman Province

\section{RESULTS AND DISCUSSION}

\section{Socio-Economic Characteristics of Breeders}

As indicated on Table 1, women constitute the minor part of breeders. More than half of the breeders aged 40 and older. The vast majority ( 63.5\%) was graduated from primary school. In the study conducted by Demirbük and Kizılaslan (2020) in Sivas Province, 72.62\% of small ruminant breeders had only primary education.

Table 1. Socio-economic characteristics of breeders.

\begin{tabular}{llc}
\hline Gender & Frequency & $(\mathbf{\% )}$ \\
\hline Women & 8 & 6.8 \\
Men & 110 & 93.2 \\
\hline Age (years) & & \\
\hline $0-26$ & 3 & 2.5 \\
$26-40$ & 41 & 34.8 \\
$41-55$ & 73 & 61.9 \\
$56-65$ & 1 & 0.8 \\
\hline Total & $\mathbf{1 1 8}$ & $\mathbf{1 0 0 . 0}$ \\
\hline Educational level & & \\
\hline Literate & 2 & 1.7 \\
Primary education & 75 & 63.5 \\
Secondary & 14 & 11.9 \\
High school & 19 & 16.1 \\
University & 8 & 6.8 \\
\hline Total & $\mathbf{1 1 8}$ & $\mathbf{1 0 0 . 0}$ \\
\hline
\end{tabular}

The average age of breeders was found as 43.9 and the year of experience was found as 21.3. Considering the age and experience, it would be stated that the breeders are in an efficient period in 
terms of production. The average number of small ruminants is 252.4 and the average land size is 15.4 hectares. The average age of breeders was found as 43.01 in a study conducted in Nigeria (Esiobu and Onubuogu, 2014). In a study conducted in Korea, the average experience of breeders was found as 21.4 years (Kim et. al., 2012). Asare-Nuamah and Botchway (2019) found that in their study in Ghana there is no significant relationship between demographic characteristics of smallholder farmers and their climate change perception.

Table 2. Average values of breeders

\begin{tabular}{lllll}
\hline & Age & Experience (years) & N of Animals (Head) & Farm size (ha) \\
\hline Mean & 43.9 & 21.3 & 252.4 & 15.4 \\
$\mathrm{~N}$ & 118 & 118 & 118 & 118 \\
Std. Deviation & 9.99 & 11.49 & 147.11 & 174.35 \\
Minimum & 21.0 & 1.0 & 20 & 0.0 \\
Maximum & 67.0 & 45.0 & 870 & 1000.0 \\
\hline
\end{tabular}

\section{The Perception of Breeders to Climate Change}

More than $90 \%$ of the breeders heard the concept of climate change whereas $85.6 \%$ believe in the climate change. However, almost all of the breeders $(94.5 \%)$ stated that they were not informed or trained on climate change. $63.6 \%$ of the breeders witnessed extreme weather conditions.

In the trend analysis given in Figure 2, it is seen that time and temperature are in the same direction with direct proportion. The average temperature was realized at 12.4 with the maximum temperature of 14.8 and the minimum temperature $9.4{ }^{\circ} \mathrm{C}$ degrees. The standard deviation of stated data is 0.99 . The increase in temperature rates throughout the years are found statistically significant at the significance level of $1 \%$ in Table 3 . As it is seen in Table $7,77.1 \%$ of breeders believe that the temperature has raised in recent years. 2010-2019, is the warmest on record globally. Since the 1980s, each successive decade has been warmer than any preceding one since 1850 (WMO, 2020). This information is in line with farmers' perceptions.

In the study conducted in Polatli District (Ankara / Turkey), an increase was found in the average annual temperature rates (Çaltı and Somuncu, 2018). In the study conducted in Nigeria, a considerable relationship was found between time and temperature with the same direction. The temperature increases in line with time and there is a significant correlation between such variables (Mbakwe et. al., 2016). According to high emission scenario (A2) model simulations, whic is basis of IPCC 4. Assesment report (AR4), compared to today, it was estimated that the annual temperature will be risen by around 3.1-5.2 ${ }^{\circ} \mathrm{C}$ in Turkey through the end of the century (Turan, 2018). While global trend seems to begin since 1980s, there had been an increasing trend in the temperature anomaly of Turkey since 1990s. Despite this delay, the temperature increase in Turkey was higher than the global temperature increase for the same period (Bozoğlu et. al., 2019). Both findings are consistent with the research results related to temperature.

Table 3. Annual temperature

\begin{tabular}{ll}
\hline Value & ${ }^{\circ} \mathbf{C}$ \\
\hline Min & 9.4 \\
Mak. & 14.8 \\
Average & 12.4 \\
Std. Deviation & 0.99 \\
Pearson Correlation & 0.57 \\
\hline
\end{tabular}




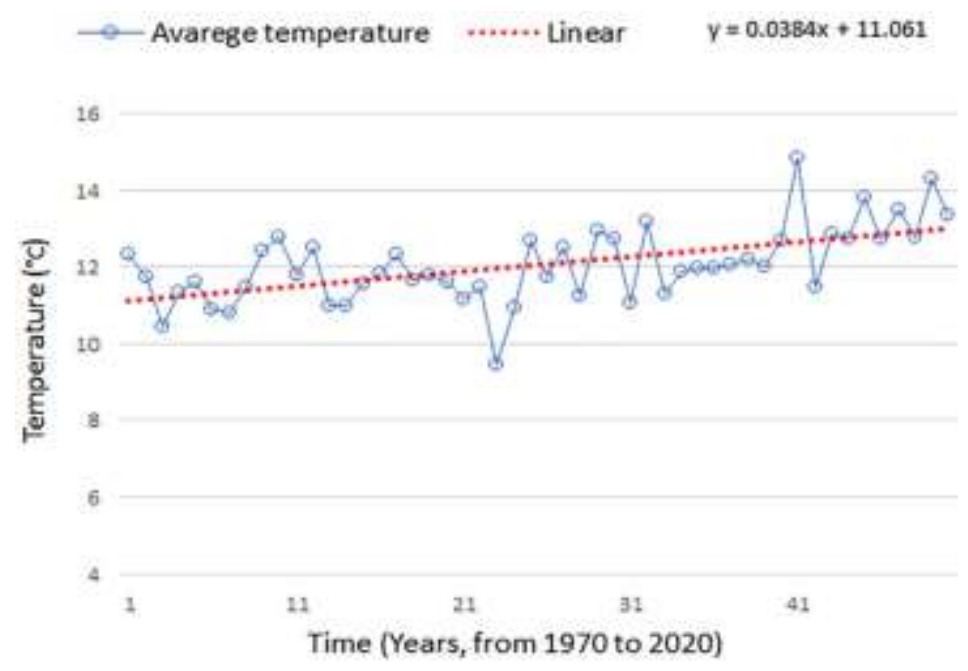

Figure 2. Temperature

As it is seen in Figure 3 and Table 4, a decrease fails to found in the average annual rainfall. The average annual rainfall is $330 \mathrm{~mm}$ with the maximum rate of $532 \mathrm{~mm}$ and the minimum rate of $212 \mathrm{~mm}$ whereas standard deviation is 73.3. The increase in rainfall is found statistically insignificant at the significance level of $1 \%$. In the study performed by Çaltı and Somuncu (2018) in Polatli District of Ankara Province, a downward tendency was observed in the amount of rainfall. In the study conducted by Mbakwe et. al. (2016), the correlation between rainfall and time was found statistically significant at the significance level of $1 \%$.

In Ghana Asare-Nuamah and Botchway (2019) found that there was an increase in annual rainfall. Researchers reported that it was specified by the IPCC a unit increase in temperature may account for 1-3\% increase in precipitation. Rising temperature in Ghana may therefore be responsible for the increasing rainfall trends observed in this study and it may be the same in Turkey.

Table 4. Annual precipitation

\begin{tabular}{ll}
\hline Value & $\mathbf{m m}$ \\
\hline Min & 212 \\
Mak. & 532 \\
Average & 330 \\
Std. Deviation & 73.3 \\
Pearson Correlation & 0.017 \\
\hline
\end{tabular}

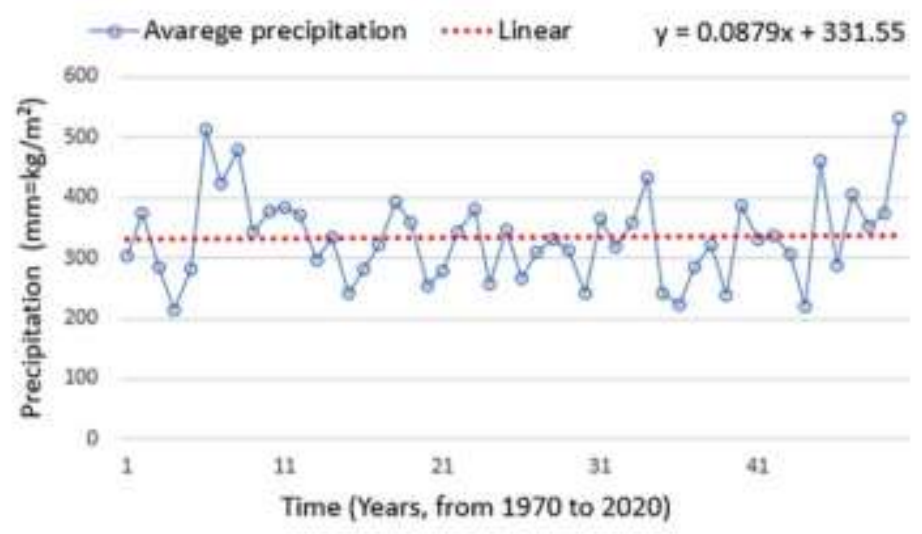

Figure 2. PrecipitationThe data concerning the number of rainy days is indicated on Figure 4 and 
Table 5. A decrease is observed in the number of rainy days. The term "“_" in this formula indicates the decrease. The decrease in the number of rainy days complies with the negative correlation coefficient. However, this decrease was found statistically insignificant at the significance level of $1 \%$.

Table 5. Annual rainy days

\begin{tabular}{ll}
\hline Value & Days \\
\hline Min & 55.00 \\
Max. & 98.00 \\
Average. & 77.50 \\
Std. Deviation & 11.09 \\
Pearson Correlation & -0.254 \\
\hline
\end{tabular}

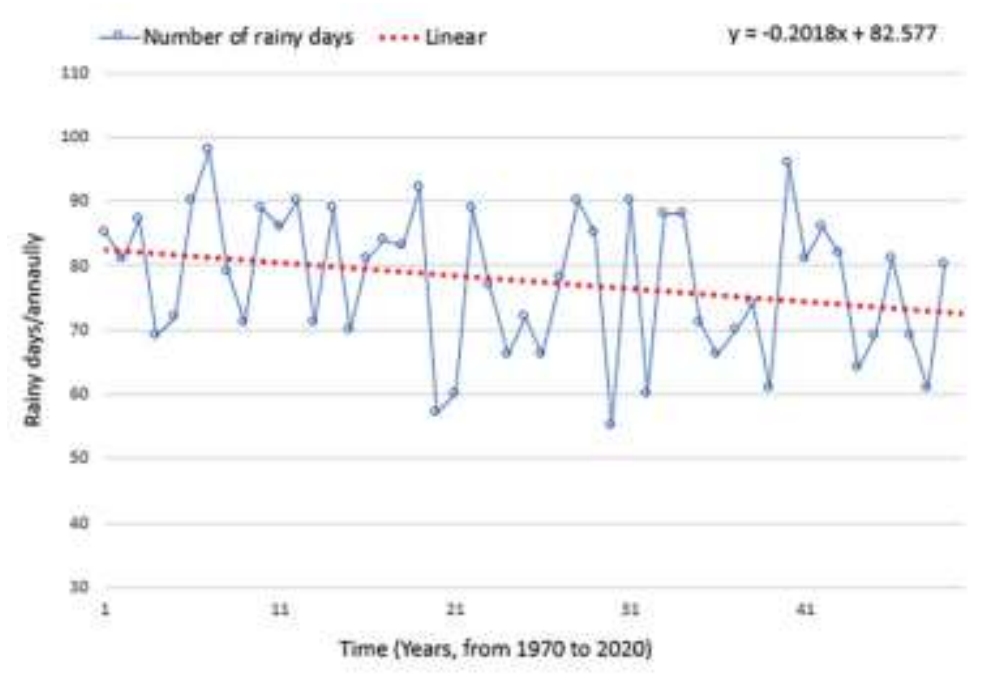

Figure 4. Number of rainy days/years

Considering the data on relative humidity indicated in Figure 5 and Table 6, the rates are marked as negative with a downward trend. The rate of decrease is statistically significant at the significance level of $1 \%$. The average relative humidity is found as $59.34 \%$ with the maximum rate of 67 and the minimum rate of 50.56 whereas standard deviation is calculated as 3.68 . In the study conducted by Mbakwe et. al. (2016), a decrease in relative humidity was observed although this rate was found statistically insignificant.

Table 6. Relative humidity, \%

\begin{tabular}{ll}
\hline Value & $\mathbf{\%}$ \\
\hline Min & 50.56 \\
Mak. & 67.00 \\
Average. & 59.34 \\
Std. Deviation & 3.68 \\
Pearson Correlation & -0.710 \\
\hline
\end{tabular}

The perception of breeders about the climate elements is given in Table 7. The perception of breeders about temperature complies with the graphic given in Figure 2 and the data of correlation analysis given in Table $3.60 \%$ of breeders believe that a decrease has been experienced in the amount of rainfall. In contrary to this perception, an increase was observed in the amount of rainfall. However, it was found statistically insignificant as indicated in Table 4. This would be the reason for the false 
perception among the breeders. The perception of breeders about the number of rainy days complies with the data indicated in Table 5. 57.6\% of the breeders ticked the option "the number of rainy days has decreased". It is considered that the decrease in the number of rainy days had an impact on the perception of breeders about the above-mentioned average rainfall. As summarized in Table 6, a statistically significant decrease was found in relative humidity. Regardless of such data, more than half of the breeders believe that there is an increase in relative humidity.

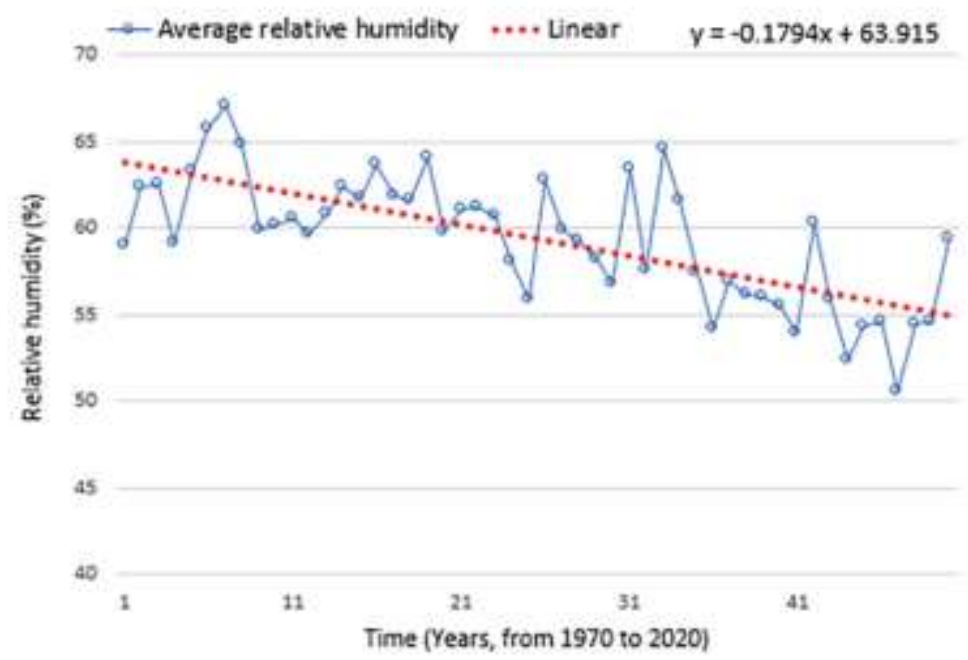

Figure 3. Relative humidity

Table 7. Perceptions of breeders about climate elements

\begin{tabular}{lllllllll}
\hline \multirow{2}{*}{ Perceptions } & \multicolumn{2}{l}{ Temperature } & \multicolumn{2}{c}{ Precipitation } & \multicolumn{2}{c}{$\begin{array}{c}\text { Number of Rainy } \\
\text { days }\end{array}$} & \multicolumn{2}{c}{ Relative Humidity } \\
\cline { 2 - 9 } & Count & \% & Count & \% & Count & \% & Count & \% \\
\hline Increased & 91 & 77.1 & 11 & 9.3 & 9 & 7.6 & 30 & 25.4 \\
Same & 23 & 19.5 & 36 & 30.5 & 41 & 34.7 & 61 & 51.7 \\
Decreased & 4 & 3.4 & 71 & 60.2 & 68 & 57.6 & 27 & 22.9 \\
Total & 118 & 100.0 & 118 & 100.0 & 118 & 100.0 & 118 & 100.0 \\
\hline
\end{tabular}

\section{The Factors Affecting Adaptation to Climate Change}

Following the literature review, a model was developed for the adaptation of breeders to climate change. The findings obtained from the analyzed model are indicated in Table 8 . The significance level of the goodness of fit index (Omnibus Test of Model Coefficients) were found as 0.000 in this model. The chi-square rate was found statistically significant, which indicates a relationship between dependent and independent variables. The Hosmer and Lemeshow test analyzing compliance of logistic regression model as a whole was found statistically insignificant (0.715). The compliance of model-data is at a sufficient level.

According to the results of logistic regression analysis, gender, educational background, number of animals, farm size, other income, agricultural income and total income are found statistically insignificant. In two studies conducted separately in Kenya, most of the measures applied an adaptation strategy for climate change are found statistically significant (Kinuthia et. al., 2018; Atsiaya et. al., 2019). In the study conducted in Benin, the level of education was found statistically significant in terms of adaptation to climate change although it should be considered that $55.8 \%$ of farmers were illiterate 
(Fadina and Barjolle, 2018). A study conducted in Ethiopia revealed that education level, gender of farmer, experience and age were positively and significantly related to farmers'adaptation decision (Astrat and Simane, 2018).

A negative relationship is found between the age of breeders and the adaptation to climate change. As the age decreases by one unit, the possibility of adaptation to climate change increases by 1.14 times. In other words, the young breeders adapt more to climate change. In the studies conducted in Nigeria, a positive relationship was found between age and adaptation (Mbakwe et. al., 2016, Esiobu and Onubuogu, 2014). In a study conducted in USA, a decrease was found in the implementation rate of adaptation options in line with the advancing age (Mase et. al., 2016). In the study conducted by Kinuthia et. al. (2018) in Nigeria, it was found that age was an effective factor as an adaptation strategy in terms of product diversification. In line with the age, the water harvesting and forest tree planting rates were found statistically significant in product range at the significance level of 1

The increase of 1 unit in experience level also raise the adaptation possibility by 1.10 times. The experience level has a positive impact in terms of adaptation, which also complies with the findings obtained for the plant cultivators in Nigeria (Mbakwe et. al., 2016) Esiobu and Onubuogu (2014) found a positive relation between the experience level and all adaptation options in their study. In the studies conducted in Korea (Kim et. al., 2012) and Benin (Fadina ve Barjolle, 2018), a statistically significant relationship was found between the experience level and the adaptation to climate change.

The case of believing or not believing in climate change was found statistically significant. Since the first group was taken as the reference category (1-yes and 2-no), a negative relationship is observed. The breeders believing in climate change has 3.7 times more adaptation possibility comparing to the contrary opinions. Astrat and Simane (2017) indicated that adaptation to climate change is a two-step process that involves perceiving that climate is changing and then responding to the change through adaptation measures.

The difference between the approaches of breeders towards innovation are found statistically significant. The approaches to innovation are classified under 3 categories (1- accepted immediately, 2accepted following observation, 3- not accepted). The first group is selected as the reference category. The individuals accepting innovation immediately has 6.66 times more adaptation possibility comparing to the individuals failing to accept innovation.

Witnessing extreme weather event is found statistically significant. Breeders, who witnessed extreme weather events, 5.38 times likely to adapt to climate change compared to others who were not witnessed. $61,9 \%$ of respondents stated that they have witnessed extreme weather events in the study area. In a study conducted in Çanakkale province of Turkey, $43.6 \%$ of the villages experienced a natural disaster due to climate change in the last 3 years (Y1ldirım and Everest, 2020). The difference of two studies may be due to the fact that the answers in the last study were taken on a village basis.

The responses given by the breeders to the questions concerning adaptation strategies are given in Table 9. In order to reduce the negative impacts of climate change, the breeders implement various strategies. The usage of concentrate feed, forage crop production, diversity in agricultural production and breeding more resistant species against diseases and droughts take one step forward among those strategies. \% 15.5 of breeders declared that they do not implement a specific strategy, nor they change the breeding techniques. 
Table 8. Variables in the equation

\begin{tabular}{|c|c|c|c|c|c|c|c|}
\hline \multirow[b]{2}{*}{ Variables } & \multirow[b]{2}{*}{ B } & \multirow[b]{2}{*}{ S.E. } & \multirow[b]{2}{*}{ Wald } & \multirow[b]{2}{*}{ Sig. } & \multirow[b]{2}{*}{$\operatorname{Exp}(\mathbf{B})$} & \multicolumn{2}{|c|}{ 95\% C.I.for EXP(B) } \\
\hline & & & & & & Lower & Upper \\
\hline Age & -0.136 & 0.052 & 6.934 & 0.008 & 0.873 & 0.789 & 0.966 \\
\hline Gender (1) & 0.082 & 1.156 & 0.005 & 0.944 & 1.085 & 0.112 & 10.469 \\
\hline Education & 0.226 & 0.360 & 0.395 & 0.530 & 1.254 & 0.619 & 2.539 \\
\hline Experience & 0.101 & 0.038 & 7.018 & $0.008 *$ & 1.106 & 1.027 & 1.192 \\
\hline Number of Animals & -0.005 & 0.009 & 0.315 & 0.575 & 0.995 & 0.978 & 1.013 \\
\hline Farm size & -0.002 & 0.011 & 0.040 & 0.841 & 0.998 & 0.977 & 1.019 \\
\hline Other income (1) & -2.031 & 2.208 & 0.846 & 0.358 & 0.131 & 0.002 & 9.937 \\
\hline Believe in CC (1) & -3.606 & 1.222 & 8.713 & $0.003 *$ & 0.027 & 0.002 & 0.298 \\
\hline Innovation & & & 10.969 & $0.004 *$ & & & \\
\hline Innovation (1) & -0.900 & 0.654 & 1.892 & 0.169 & 0.407 & 0.113 & 1.466 \\
\hline Innovation (2) & -4.199 & 1.276 & 10.835 & $0.001 *$ & 0.015 & 0.001 & 0.183 \\
\hline Extreme weather events (1) & 1.684 & 0.679 & 6.152 & $0.013 *$ & 5.385 & 1.424 & 20.370 \\
\hline Total income & -0.034 & 0.065 & 0.276 & 0.600 & 0.967 & 0.851 & 1.097 \\
\hline Agricultural income & 0.069 & 0.088 & 0.626 & 0.429 & 1.072 & 0.903 & 1.273 \\
\hline Constant & 4.490 & 3.397 & 1.747 & 0.186 & 89.112 & & \\
\hline
\end{tabular}

a. Variable(s) entered on step 1: Age, Gender, Education, Experience, Number of Animals, Farm size, Other income, Believe in CC, Innovation, Extreme weather events, Total income, Agricultural income Initial -2 Log Likelihood: 158.667, goodness of fit; 63.417, sig; $0.000, \mathrm{P}<0.05$

Hosmer and Lemeshow Test; Chi-square; 5.394, Sig; 0.715, P>0.05

Cox \& Snell R Square; 0.416, Nagelkerke R Square; 0.562

In this analysis, the first group of categorical independent variables was selected as the reference group and comments were made accordingly. Those whose probability ratio is less than 1 are explained by the inverse value of this value (1/ Exp (B)).

Table 9. Adaptation strategies of breeders

\begin{tabular}{|c|c|c|c|}
\hline \multirow[b]{2}{*}{ Adaptation Strategies } & \multicolumn{2}{|c|}{ Responses } & \multirow[t]{2}{*}{$\%$} \\
\hline & $\mathbf{N}$ & $\%$ & \\
\hline No action & 46 & 15.5 & 39.0 \\
\hline Diversity in agricultural production & 37 & 12.5 & 31.4 \\
\hline Transfer from other income & 4 & 1.3 & 3.4 \\
\hline Use water and other natural resources more effectively and efficiently & 18 & 6.1 & 15.3 \\
\hline Planned grazing in the rangelands & 5 & 1.7 & 4.2 \\
\hline use farm manure in the field & 27 & 9.1 & 22.9 \\
\hline More forage crops & 37 & 12.5 & 31.4 \\
\hline More concentrate feed & 43 & 14.5 & 36.4 \\
\hline Resistant breeds against diseases, pests and droughts & 35 & 11.8 & 29.7 \\
\hline Adjusting the times for insemination & 18 & 6.1 & 15.3 \\
\hline Adjusting vaccination, spraying times & 27 & 9.1 & 22.9 \\
\hline Total & $297 *$ & 100.0 & 251.7 \\
\hline
\end{tabular}

* Multiple Responses

Certain questions were asked to the breeders about the challenges encountered in preventing from the negative impacts of climate change and the responses were summarized in Table 10. The option "lack of information about climate change and its effects" takes one step forward among those responses. The other prominent options refer to the insufficient government aids and the lack of regular contact with authorities. The failure to obtain sufficient information was described as the major barrier encountered by the breeders in Nigeria (Esiobu and Onubuogu, 2014, Mbakwe et. al., 2016). In parallel to this finding, in the study conducted in Ethiopia (Deressa et. al., 2011), the breeders having difficulties in terms of adaptation to climate change have underlined the lack of knowledge as one of the main 
reasons. Zizinga et. al. (2017) conducted a study in Uganda and specified the insufficiencies in knowhow, financing, labor force and irrigation infrastructure as the major barriers against the adaptation phase. In Çanakkale provience $74.5 \%$ of the members of cooperative management boards stated that they would like to receive training on combating climate change (Y1ldırım and Everest, 2020).

Table 10. Barriers to climate change adaptation faced by breeders

\begin{tabular}{llll}
\hline Constrains & Responses & \multicolumn{1}{c}{} \\
& $\mathbf{N}$ & $\mathbf{\%}$ & \\
\hline Lack of information about climate change and its effects & 96 & 44.9 & 81.4 \\
lack of regular contact with the Consultant/Agents & 34 & 15.9 & 28.8 \\
Lack of Capital / Credit & 15 & 7.0 & 12.7 \\
Expensive input & 24 & 11.2 & 20.3 \\
Insufficient government aid & 44 & 20.6 & 37.3 \\
Others & 1 & 0.5 & 0.8 \\
Total & $214^{*}$ & 100.0 & 181.4 \\
\hline
\end{tabular}

* Multiple Responses

\section{CONCLUSION}

In order to reduce the negative impacts of climate change and to maintain food security, the adaptation of breeders to climate change is very critical. Although the breeders believe in climate change, it should be considered in the scope of this study that the perception of breeders fails to be compatible with rainfall and relative humidity data. It is critical to eliminate this incompatibility. The consequences of climate change on regional basis shall be advised to the breeders together with the direction of expected change and its outcome.

Age, experience, approach to innovations and believing in climate change are found as the factors affecting the adaptation of breeders to climate change. New techniques, species and types should be introduced through young breeders. New techniques should include the adaptation of climate change as well as the measures reducing the negative impact of agricultural production on greenhouse gas emissions.

The lack of adequate and reliable information steps forward among the factors constraining adaptation to climate change. The training activities should be organized for regular notifications concerning the impacts of climate change on agricultural production and future projection. In this respect, it is important extension agents to become fully equipped. Restructuring government aids in consideration of regional climate conditions shall facilitate the adaptation of breeders.

The detailed studies concerning the impacts of climate change on agricultural production are needed in Turkey. All sub-components of agricultural production (field crop cultivation, fruit and vegetable production, small ruminant breeding, cattle breeding, poultry farming, etc.) should be discussed separately.

The relevant policies and intervention methods for this issue should be developed through the cooperation between all parties such as public institutions, research institutes and universities.

\section{REFERENCES}

Akalın M. 2014. The climate change impacts on agriculture: adaptation and mitigation strategies for these impacts. Hitit University Journal of Social Sciences Institute, 7(2):351-377.

Asare-Nuamah, P., \& Botchway, E. (2019). Comparing smallholder farmers' climate change perception with climate data: the case of Adansi North District of Ghana. Heliyon, 5 (12):1-12. 
Asrat P, Simane S. 2017. Adaptation benefits of climate-smart agricultural practices in the Blue Nile Basin: empirical evidence from North-West Ethiopia. In: Filho WL, Belay S, Kalangu J, Menas W, Munishi $\mathrm{P}$, Musiyiwa K (eds) Climate change adaptation in Africa: fostering African resilience and capacity to adapt. Vol. 1. Springer International Publishing AG, Cham, Switzerland

Asrat P, Simane B. 2018. Farmers' perception of climate change and adaptation strategies in the Dabus watershed, North-West Ethiopia. Ecol Process 7(7), 1-23.

Atsiaya GO, Ayuya, OI, Nakhone LW, 2019. Drivers and responses to climate variability by agropastoralists in Kenya: the case of Laikipia County. SN Applied Sciences, 1(8):827.

Bozoglu M, Başer U, Alhas Eroglu N, Kılıc Topuz B, 2019. Impacts of climate change on turkish agriculture . Journal of International Environmental Application and Science , 14 (3) , 97-103

Çaltı N, Somuncu M, 2018. Perception and adaptation levels of farmers about the impact of climate change on agriculture in the Polatlı district of Ankara province. International Geography Symposium on the $30^{\text {th }}$ Anniversary of TUCAUM 3-6 October 2018, Ankara

Demirbük M, Kizilaslan N, 2020. Analysis of relationships between breeders' associations and their, A case study of Sivas. KSU Journal Of Agriculture and Nature. 23(1):194-211.

Deressa T, Hassan R, Ringler C, 2011. Perception of and adaptation to climate change by farmers in the Nile basin of Ethiopia. The Journal of Agricultural Science, 149(1):23-31.

Esiobu NS, Onubuogu GC, 2014. Trends, Perceptions and adaptation options of livestock farmers to climate change in Imo State, Nigeria: A Multinomial Logit Model Approach. Journal of Economics and Sustainable Development, 5(19):21-36.

Fadina AMR, Barjolle D, 2018. Farmers' adaptation strategies to climate change and their implications in the Zou Department of South Benin. Environments, 5, 15.

FAO 2015. Climate change and food systems: global assessments and implications for food security and trade. Food Agriculture Organization of the United Nations (FAO).

FAO 2017. Climate-smart Livestock Production. Retrieved in April, 12, 2011 from http://www.fao.org/climate-smart-agriculture-sourcebook/production-resources/module-b2livestock/b2-overview/en/?type $=111$

FAO 2018. The impact of disasters and crises on agriculture and food security 2017, http://www.fao.org/3/I8656EN/i8656en.pdf. (Date of access: 8 September 2020).

FAO 2019. Agriculture and climate change - Challenges and opportunities at the global and local Level Collaboration on Climate-Smart Agriculture. Rome. 52 pp. Licence: CC BY-NC-SA 3.0 IGO.

Kim CS, \& Jung, HK, Lee, SH, Park, SY, Takei A, 2012. "An analysis on determinants of farmers' adaptation to climate change in Korea," Journal of Rural Development/Nongchon-Gyeongje, Korea Rural Economic Institute, 35(2):1-20.

Kinuthia KJ, Inoti SK, Nakhone L. 2018. Factors influencing farmer'sc of crop production response strategies to climate change and variability in Narok East Sub-county, Kenya. Journal of Natural Resources and Development, (8):69-77.

Mase AS, Gramig BM, Prokopy LS, 2017. Climate change beliefs, risk perceptions, and adaptation behavior among Midwestern U.S. crop farmers. Climate Risk Management, (15):8-17

Mbakwe I, Judith O, Obaji N, 2016. A study of socio-economic characteristics of farmers to determined their perceptions on climatic variables and adaptation options in Imo State, Nigeria. African Journal of Agricultural Economics and Rural Development, 4(2):287-300.

MEU 2012. Turkey's National Climate Change Adaptation Strategy and Action Plan. Retrieved in April, 15, 2020 from http://www.dsi.gov.tr/docs/iklim-degisikligi/turkeys-national-climate-change-adaptationstrategy-and-action-plan.pdf?sfvrsn=2

Mitter H, Larcher M, Schönhart M, Stöttinger M, Schmid E, 2019. Exploring farmers' climate change perceptions and adaptation intentions: empirical evidence from Austria. Environmental Management, (63):804-821. 
Polat K, Dellal İ, 2016. Climate change perception of rice producers and determination of effective factors in making good agricultural practices. The Journal of Agricultural Economics Researches (JAER), 2(2):46-54.

Soylu S, Sade B, 2012. A Research Project on the Effects of Climate Change on Agricultural Products. $\begin{array}{lllll}\text { Retrieved in } & \text { March, } & 3, & 2020 & \text { from }\end{array}$ http://www.konyadayatirim.gov.tr/images/dosya/\%C4\%B0klim\%20De\%C4\%9Fi\%C5\%9Fikli\%C4 \%9Finin\%20Tar\%C4\%B1msal\%20\%C3\%9Cr\%C3\%BCnlere\%20Etkisi\%20\%C3\%9Czerine\%20Bir $\% 20 \mathrm{Ara} \% \mathrm{C} 5 \% 9 \mathrm{Ft} \% \mathrm{C} 4 \% \mathrm{~B} 1 \mathrm{rma} . \mathrm{pdf}$

Turan E. 2018. Turkey's drought status associated with climate change. Journal of Natural Hazards and Environment, 4(1):63-69

WMO 2020. WMO Statement on the state of the global climate in 2019. No:1248

Woods B, Nielsen HØ, Pedersen AB, Kristofersson DM, 2017. Farmers' Perceptions of climate change and their likely responses in Danish Agriculture. Land Use Policy, 65:109-120.

Yadav SS. Hegde VS. Habibi AB. Dia M, Verma S. 2019. Climate change, agriculture and food security. In Food Security and Climate Change; Yadav, S.S., Redden, R.J., Hatfield, J.L., Ebert, A.W., Hunter, D., Eds.; John Wiley \& Sons Ltd: Hoboken, NJ, USA, (Book Chapter) pp 1-24

Yamane, T., 2006. Basic Sampling Methods. Nobel Press, 509 p, Ankara.

Y1ldırım M, Everest B, 2020. Renewable energy awareness of agricultural cooperatives: the case of Çanakkale Province. COMU J. Agric. Fac. 8(1): 233-241

Zizinga A, Kangalawe R, Ainslie A, Tenywa M, Majaliwa J, Saronga N, Amoako E, 2017. Analysis of farmer's choices for climate change adaptation practices in South-Western Uganda, 19802009. Climate, 5(4):89. 